\title{
Seasonal and long term variations of surface ozone concentrations in Malaysian Borneo
}

Mohd Talib Latif ${ }^{\mathrm{a}, \mathrm{b} *}$, Doreena Dominick ${ }^{\mathrm{a}, \mathrm{c}}$, Fatimah Ahamad ${ }^{\mathrm{a}}$, Nur Shuhada Ahamad ${ }^{\mathrm{a}}$, Md Firoz Khan $^{\mathrm{d}}$, Liew Juneng ${ }^{\mathrm{a}}$, Chung Jing Xiang ${ }^{\mathrm{a}}$, Mohd Shahrul Mohd Nadzir ${ }^{\mathrm{a}, \mathrm{d}}$, Andrew D. Robinson $^{\mathrm{e}}$, Marzuki Ismail ${ }^{\mathrm{f}}$, Mohammed Iqbal Mead ${ }^{\mathrm{g}}$, Neil R. P. Harris ${ }^{\mathrm{g}}$

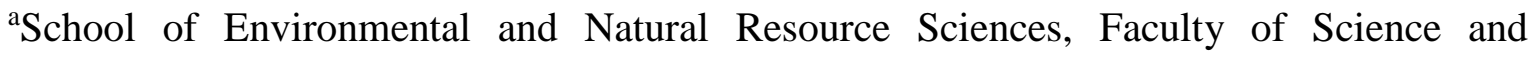
Technology, Universiti Kebangsaan Malaysia, 43600 Bangi, Selangor, Malaysia.

${ }^{\mathrm{b}}$ Institute for Environment and Development (LESTARI), Universiti Kebangsaan Malaysia, 43600 Bangi, Selangor, Malaysia.

${ }^{c}$ Centre for Atmospheric Chemistry, University of Wollongong, Wollongong, NSW, 2522 Australia

${ }^{\mathrm{d}}$ Research Centre for Tropical Climate Change System, Faculty of Science and Technology, Universiti Kebangsaan Malaysia, 43600 Bangi, Selangor, Malaysia.

${ }^{e}$ Centre of Atmospheric Sciences, Chemistry Department, University of Cambridge, Cambridge CB2 1EW, United Kingdom

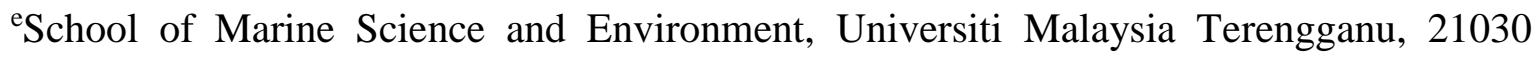
Kuala Terengganu, Terengganu, Malaysia

${ }^{\mathrm{g}}$ Centre for Atmospheric Informatics and Emissions Technology, Cranfield University, Cranfield, MK43 0AL, United Kingdom.

*Corresponding author

E-mail: talib@ukm.edu.my

Tel: $+603-89214145$

Fax: +603-89255104 


\section{Abstract}

Malaysian Borneo has a lower population density and is an area known for its lush rainforests. However, changes in pollutant profiles are expected due to increasing urbanisation and commercial-industrial activities. This study aims to determine the variation of surface $\mathrm{O}_{3}$ concentration recorded at seven selected stations in Malaysian Borneo. Hourly surface $\mathrm{O}_{3}$ data covering the period 2002 to 2013, obtained from the Malaysian Department of Environment (DOE), were analysed using statistical methods. The results show that the concentrations of $\mathrm{O}_{3}$ recorded in Malaysian Borneo during the study period were below the maximum Malaysian Air Quality Standard of 100 ppbv. The hourly average and maximum $\mathrm{O}_{3}$ concentrations of 31 and 92 ppbv reported at Bintulu (S3) respectively were the highest among the $\mathrm{O}_{3}$ concentrations recorded at the sampling stations. Further investigation on $\mathrm{O}_{3}$ precursors shows that sampling sites located near to local petrochemical industrial activities, such as Bintulu (S3) and Miri (S4), have higher $\mathrm{NO}_{2} / \mathrm{NO}$ ratios (between 3.21 and 5.67) compared to other stations. The normalised $\mathrm{O}_{3}$ values recorded at all stations were higher during the weekend compared to weekdays (unlike its precursors) which suggests the influence of $\mathrm{O}_{3}$ titration by $\mathrm{NO}$ during weekdays. The results also show that there are distinct seasonal variations in $\mathrm{O}_{3}$ across Borneo. High surface $\mathrm{O}_{3}$ concentrations were usually observed between August and September at all stations with the exception of station S7 on the east coast. Majority of the stations (except S1 and S6) have recorded increasing averaged maximum concentrations of surface $\mathrm{O}_{3}$ over the analysed years. Increasing trends of $\mathrm{NO}_{2}$ and decreasing trends of $\mathrm{NO}$ influence the yearly averaged maximum of $\mathrm{O}_{3}$ especially at $\mathrm{S} 3$. This study also shows that variations of meteorological factors such as wind speed and direction, humidity and 
temperature influence the concentration of surface $\mathrm{O}_{3}$.

Keywords: Surface ozone; ozone precursors; meteorological factors; seasonal variations

\section{Introduction}

Surface ozone $\left(\mathrm{O}_{3}\right)$ is a major air pollutant that impacts human health, materials and vegetation (Anenberg et al., 2009; Ishii et al., 2007; Lee et al., 1996). Studies by Levy et al. (2005) and Bell et al. (2014) have shown that $\mathrm{O}_{3}$ can contribute to higher mortality, especially for elderly people. Several studies, such as West et al. (2006), Jerrett et al. (2009), Guo et al. (2014) and Yang et al. (2014) have indicated that high concentrations of surface $\mathrm{O}_{3}$ can cause cardiovascular and respiratory dysfunction. The impact of $\mathrm{O}_{3}$ on human health was found to be further influenced by increasing temperature (Ren et al., 2008). High concentrations of $\mathrm{O}_{3}$ also damage materials, such as surface coatings and rubber goods, and plants, via membrane damage on leaves therefore effecting the photosynthesis processes (Chaudhary and Agrawal, 2015; Lee et al., 1996). Studies have also shown that surface $\mathrm{O}_{3}$ can reduce the yield of certain food crops such as paddy-grown rice and grain (Amin, 2014; Debaje, 2014; Ghude et al., 2014; Van Dingenen et al., 2009; Wang and Mauzerall, 2004).

The change of land use from forest to agricultural, residential and urban use has created a change in the $\mathrm{O}_{3}$ precursor environment, which can be seen clearly between urban and rural areas (Kulkarni et al., 2016; Tu et al., 2007; Xie et al., 2016). This phenomenon usually leads to the formation of high concentrations of $\mathrm{O}_{3}$ downwind and in suburban areas due to increased concentrations of $\mathrm{O}_{3}$ precursors generating high concentrations of 
$\mathrm{O}_{3}$ (An et al., 2015; Latif et al., 2012). The high intensity of sunlight in tropical regions accelerates the process of $\mathrm{O}_{3}$ formation (Ahamad et al., 2014; Awang et al., 2016a; Banan et al., 2013; Latif et al., 2012). Motor vehicles and industrial activities are the main sources of $\mathrm{O}_{3}$ precursors such as NOx and CO (Vingarzan, 2004; Xie et al., 2016). Areas with high volumes of vehicles have increased NO levels, which can then produce high concentrations of $\mathrm{NO}_{2}$. The transport of $\mathrm{NO}_{2}$ downwind will release $\mathrm{O}$ radicals which will then interact with $\mathrm{O}_{2}$ to form $\mathrm{O}_{3}$. At the same time, high concentrations of $\mathrm{NO}$ will effectively titrate $\mathrm{O}_{3}$ in urban areas. Volatile organic compounds (VOCs) are other precursors of $\mathrm{O}_{3}$ that can be emitted from anthropogenic as well as natural sources (Shao et al., 2016; Tie et al., 2006). Forest areas have been found to contribute to the high levels of VOCs; an example is isoprene which can transform to other organic peroxides and then contribute to enhanced concentrations of the O radical (Stavrakou et al., 2014; Taraborrelli et al., 2012). The combination of anthropogenic and biogenic $\mathrm{O}_{3}$ precursor species usually leads to high concentrations of $\mathrm{O}_{3}$ in the areas between highly populated urban centres and more forested or rural areas.

The island of Borneo is internationally recognised for its extensive, diverse and relatively untouched environment. The expansion of urban areas due to increasing population has changed the landscape of this island. However, agricultural activities are still the main economic generators for this area. Information on $\mathrm{O}_{3}$ and precursor trends could indicate the potential need for mitigation measures. Studies by Sicard et al. (2013) and Sicard et al. (2016) for example, have analysed pollutant trends to evaluate effectiveness of $\mathrm{O}_{3}$ control measures and determine more suitable standards for human health and environmental 
protection. This study aims to determine the variations, particularly seasonal cycles and long term changes of surface $\mathrm{O}_{3}$ in Borneo based on long term observational data provided by the Malaysian Department of Environment (DOE). The concentration of surface $\mathrm{O}_{3}$ in relation to concentrations of $\mathrm{O}_{3}$ precursors such as $\mathrm{NO}_{\mathrm{x}}, \mathrm{CO}$ and VOCs as well as other meteorological factors, such as wind speed and direction, UV radiation and temperature were analysed.

\section{Methodology}

\subsection{Study area}

Borneo is the largest island in Asia and home to one of the oldest rainforests in the world. The island is divided among three countries, Malaysia and Brunei in the north and Indonesia to the south. In the north, the East Malaysian states of Sabah, Sarawak and the federal territory of Labuan make up about $26 \%$ of the island. Kalimantan is located in the southern part of Borneo and belongs to Indonesia. Most major towns in Borneo are located in coastal areas due to the mountainous setting in the middle of the island. During the dry season, especially between January and March, and between July and September every year, biomass burning from peat swamp areas usually affects the air quality over Borneo.

This study analysed the variation of $\mathrm{O}_{3}$ concentrations recorded at stations managed by Alam Sekitar Sdn Bhd (ASMA), a company which measures the air quality status on behalf of the Malaysian DOE in Sabah and Sarawak, Malaysian Borneo. Seven air quality stations in different areas around North Borneo had been chosen based on the availability of the $\mathrm{O}_{3}$ air quality data during the study time period (Figure 1). Kuching station (S1) is 
located at a medical store in Pending Industrial Estate, Kuching, Sarawak. This area is located on the outskirts of Kuching city. Sibu station (S2) is located at the Sibu Police Headquarters, close to the roadside in the city centre of Sibu. Both Kuching and Sibu stations are in busy areas where high volume of motor vehicles going in and out of the industrial areas, particularly during the rush hour. Bintulu station (S3) is located at the Bintulu Police Headquarters, on the outskirts of Bintulu city centre. The station is close to a less busy road next to a river, while to the north is an industrial area dominated by petrochemical industries (Liquid Natural Gas). Miri station (S4) is located in a school compound in the city centre of Miri near to a busy road. Miri is also located near to the border of Brunei. Both Miri and Brunei have extensive petroleum-related industries in the area. Labuan station (S5) is located in a housing area in centre of the Labuan Island. The station is located in the north of Labuan city. This station is expected to have less influence from motor vehicles compared to other stations. Kota Kinabalu station (S6) is located in a school compound in Putatan, a small town to the south of Kota Kinabalu city centre. The air quality is expected to be affected by the expansion of Kota Kinabalu city towards the south, including Putatan town. The number of motor vehicles during rush hour may influence the level of air pollutants at the station. Tawau station (S7) is located in a residential area of Tawau on the east coast of Sabah. The station located to the east of Tawau city centre which is one of the main towns on the east coast of Sabah. Detailed locations of the sampling points are presented in Supplementary 1.

\section{[Figure 1]}

\section{[Supplementary 1]}




\subsection{Ozone and other parameter data collection}

The air pollution data recorded at the ASMA stations between January 2002 and December 2013 includes the hourly average of surface $\mathrm{O}_{3}$ concentrations, oxides of nitrogen ( $\mathrm{NO}$ and $\mathrm{NO}_{2}$ ), and carbon monoxide $(\mathrm{CO})$. In addition to air pollutant parameters, the stations also recorded temperature, relative humidity, wind speed and wind direction. For Kuching station $(\mathrm{S} 1)$, non-methane hydrocarbon $(\mathrm{NmHC})$ and $\mathrm{UV}_{\mathrm{b}}$ radiation were also recorded.

The surface $\mathrm{O}_{3}$ concentrations at the ASMA air monitoring stations were measured using the UV Absorption $\mathrm{O}_{3}$ Analyser (Teledyne Model 400A, USA). The analyser uses a system based on the Beer-Lambert law for measuring low ranges of $\mathrm{O}_{3}$ in ambient air. The concentrations of $\mathrm{NO}$ and $\mathrm{NO}_{2}$ were determined via chemiluminescence measurement, coupled with state-of-the-art microprocessor technology, used for monitoring high and medium levels of nitrogen oxides (Teledyne Models 200A, USA). Meanwhile, the concentrations $\mathrm{CO}$ and $\mathrm{NmHC}$ (representing total VOCs) were only determined at Kuching station (S1) and were measured using infrared energy absorption (Teledyne Model 300) and the field-proven Flame Ion Detector (FID) (Teledyne Model 4020, USA) respectively (Latif et al. 2012).

\subsection{Data analysis}

The daily maximum concentrations were used to compare the surface $\mathrm{O}_{3}$ concentrations in different months and years. For the purpose of examining the relationship between $\mathrm{O}_{3}$ concentrations and its precursors recorded at particular stations ( $\mathrm{NO}, \mathrm{NO}_{2}$ and $\mathrm{CO}$ ), hourly 
data were used. The missing values for the data collected during the study period were between 6 to $12 \%$. (Table 1). Missing values in the study period are not considered in the computation of statistics.

\section{[Table 1]}

\section{$2.4 \quad$ Trajectories analysis}

Hybrid Single Particle Langragian Integrated Trajectory model (HYSPLIT version 4.9) developed by the National Oceanic and Atmospheric Administration (NOAA)'s Air Resource Laboratory (ARL) was employed to calculate $72 \mathrm{~h}$ back trajectories to determine origin of air mass arriving at the monitoring stations (Draxler et al., 2013). The height level selected for model calculation was $500 \mathrm{~m}$ to ensure that the trajectories started in the atmospheric boundary layer (Eva and Lambin, 1998). The meteorological drivers used to compute the trajectories from 2012 to 2013 were obtained from the National Centers for Environmental Prediction (NCEP) archive which is maintained by ARL. The one year period was selected as a representative year to examine the general transport pattern driven by the synoptic monsoon circulation and 2013 is also a year with reported haze occurrence. In order to compare the origin of air mass between two monsoon periods, clustering method in HYSPLIT model was also used to group the trajectories obtained based on curvature, length and transport characteristics.

\section{Results and discussion}

\subsection{Descriptive analysis}

The descriptive statistics of hourly surface $\mathrm{O}_{3}$ concentrations from 2002 until 2013 are presented in Table 1 . The hourly average concentrations of surface $\mathrm{O}_{3}$ at the monitoring stations were recorded between 24 and 31 ppbv. Bintulu (S3) and Labuan (S5) stations 
both recorded the highest average surface $\mathrm{O}_{3}$ concentrations ( $31 \mathrm{ppbv}$ ). This was followed by Miri (S4), Sibu (S2), Kota Kinabalu (S6), Tawau (S7) and Kuching (S1). The median values were close to the average $\mathrm{O}_{3}$ concentration $( \pm 2 \mathrm{ppbv}$ ) while the standard deviation for the dataset was between 8 and 11 ppbv for all the stations. Although Labuan (S5) is the only monitoring station located at an altitude of higher than $10 \mathrm{~m}$ above sea level (ASL), its altitude is only $15 \mathrm{~m}$ ASL. Its average and median $\mathrm{O}_{3}$ concentrations were similar to that of Bintulu station (S3) while its maximum $\mathrm{O}_{3}$ concentration fell within the range of 61 - 92 ppbv recorded by the seven stations. There were significant differences $(p<0.05)$ in overall hourly surface $\mathrm{O}_{3}$ concentrations between the surface $\mathrm{O}_{3}$ recorded at the different monitoring stations. The different background atmospheric compositions at the urban and suburban stations, due to the different local emissions of $\mathrm{O}_{3}$ precursors from motor vehicles and industrial activities, is thought to be the main reason for the different $\mathrm{O}_{3}$ concentrations across all stations in long term hourly measurements (Banan et al., 2013).

Surface $\mathrm{O}_{3}$ concentrations in Borneo are considered low compared to similar studies focusing on the Klang Valley, the busiest area located around Kuala Lumpur, the capital city of Malaysia (Ahamad et al., 2014; Banan et al., 2013; Latif et al., 2012). The stations located within and around Klang Valley frequently recorded maximum hourly concentrations that exceeded the limit of Malaysian Air Quality Standard of 100 ppbv. In Malaysian Borneo, the highest hourly concentration recorded was 92 ppbv at Bintulu station (S3). The concentrations of surface $\mathrm{O}_{3}$ in Borneo were closer to the $\mathrm{O}_{3}$ concentrations observed in two rural areas in Thailand (Inthanon and Srinakarin) by Pochanart et al. (2001) and eastern Thailand by Assareh et al. (2016). Higher surface $\mathrm{O}_{3}$ 
concentrations were recorded in the densely populated residential-commercial area of Jakarta, Indonesia (Permadi and Kim Oanh, 2008). The lower concentrations recorded in these stations in Malaysian Borneo are expected due to the lower concentrations of surface $\mathrm{O}_{3}$ precursors emitted from motor vehicles and industrial activities compared to the stations in the big cities such as Kuala Lumpur and Jakarta. The lower emissions of $\mathrm{O}_{3}$ precursors will reduce the ability of surface $\mathrm{O}_{3}$ to be produced around the downwind areas. Nevertheless, the stations in Borneo recorded surface $\mathrm{O}_{3}$ concentrations higher than the surface $\mathrm{O}_{3}$ recorded at the Malaysian Department of Environment (DOE) background stations in Jerantut, Pahang. The average concentration recorded here is around 13 ppbv for surface $\mathrm{O}_{3}$, as shown by Latif et al. (2012), Banan et al. (2013) and Latif et al. (2014).

\subsection{Diurnal pattern of surface $\mathrm{O}_{3}$ concentrations}

The diurnal pattern of air pollutants recorded in this study, as well as the $\mathrm{UV}_{\mathrm{b}}$ recorded at S1, showed similar patterns to previous studies (Ahamad et al., 2014; Awang et al., 2016a; Banan et al., 2013; Latif et al., 2012). $\mathrm{O}_{3}$ showed a single peak during daylight hours while the precursor concentrations showed bimodality which is attributed to traffic patterns (Figure 2). The concentration of surface $\mathrm{O}_{3}$ was highest at midday at $\mathrm{S} 1$, when the intensity of $\mathrm{UV}_{\mathrm{b}}$ was at the highest level. A high level of sunlight will encourage the formation of the $\mathrm{O}$ radical, which is responsible for the formation of $\mathrm{O}_{3}$ from its precursors such as $\mathrm{NO}_{\mathrm{x}}$ and VOCs (Awang et al., 2016b; Xie et al., 2016; Zhang et al., 2014). The concentrations of $\mathrm{O}_{3}$ precursors such as $\mathrm{CO}, \mathrm{NO}, \mathrm{NO}_{2}$ and $\mathrm{NmHC}$ (recorded at $\mathrm{S} 1$ only) recorded at their highest levels during rush hour between 7:00 and 9:00 am. At midday, the concentrations of these precursors were very low, due to their transformation to other 
secondary species of pollutants (including $\mathrm{O}_{3}$ ) as well the convective transfer of pollutants to higher altitudes. The concentrations of the surface $\mathrm{O}_{3}$ precursors peaked again in the evening when people travel back home from work. The concentrations of $\mathrm{O}_{3}$ precursors showed a less steep drop at night due to the higher atmospheric stability during the night and the absence of sunlight, reducing the scavenging reaction of photochemical oxidants (Awang et al., 2015).

\section{[Figure 2]}

\subsection{Ratio between $\mathrm{NO}_{2}$ and $\mathrm{NO}$}

The ratio of $\mathrm{NO}_{2} / \mathrm{NO}$ has been used as an indicator to determine the shift in equilibrium towards the formation of $\mathrm{O}_{3}$ from $\mathrm{NO}_{2}$. When the ratio is high, $\mathrm{O}_{3}$ formation is typically favoured as $\mathrm{NO}$ can both contribute to the formation of $\mathrm{NO}_{2}$ and the destruction of $\mathrm{O}_{3}$ (Ismail et al., 2016; Xie et al., 2016). Table 2 shows the ratio of $\mathrm{NO}_{2} / \mathrm{NO}$ during the period when the $\mathrm{O}_{3}$ peak is typically observed. The ratio is calculated based on total averaged NO and $\mathrm{NO}_{2}$ concentrations. The ratios were recorded at higher values at both $\mathrm{S} 3$ and $\mathrm{S} 4$ while all other stations recorded a consistent ratio close to one. These two stations are located in the areas associated with petrochemical industries which have the potential to release high amount of $\mathrm{NO}_{\mathrm{x}}$ and VOCs. The other stations, located in the city centre and suburban as well industrial areas, did not indicate any excess of $\mathrm{NO}_{2}$ over $\mathrm{NO}$. This result is similar to the study by Latif et al. (2012) in Peninsular Malaysia, which showed that stations with high $\mathrm{NO}_{2} / \mathrm{NO}$ ratios, especially in suburban areas, recorded high concentrations of $\mathrm{O}_{3}$ compared to stations in the city centre. 
The $\mathrm{NO}_{2} / \mathrm{NO}$ ratios indicate that there is potential for high $\mathrm{O}_{3}$ generation due to the formation of $\mathrm{NO}_{2}$ from $\mathrm{NO}$ at two of the stations ( $\mathrm{S} 3$ and $\mathrm{S} 4$ ). During the day, $\mathrm{NO}_{2}$ can be quickly photo-dissociated with subsequent $\mathrm{O}_{3}$ formation. However, $\mathrm{NO}_{2}$ release at night and in the early morning can influence nearby areas and produce high amounts of $\mathrm{O}_{3}$ at midday as suggested by Geng et al. (2008). Overall interactions of $\mathrm{NO}_{\mathrm{x}}$ at the sampling station (b) from its potential source areas (a) was explained by Geng et al. (2008) as below. Titration process at (b) will reduce the concentration of $\mathrm{O}_{3}$ at the sampling station.

$\begin{array}{llll}\mathrm{NO}(\mathrm{a})+\mathrm{O}_{3}(\mathrm{a}) & \rightarrow & \mathrm{NO}_{2}(\mathrm{a})+\mathrm{O}_{2} & \text { (at location a) } \\ \mathrm{NO}_{2}(\mathrm{a}) & \rightarrow & \mathrm{NO}_{2}(\mathrm{~b}) & \text { (transport to location } \mathrm{b}) \\ \mathrm{NO}_{2}(\mathrm{~b})+h v & \rightarrow & \mathrm{NO}(\mathrm{b})+\mathrm{O}(\mathrm{b}) & (\text { at location } \mathrm{b}) \\ \mathrm{O}(\mathrm{b})+\mathrm{O}_{2} & \rightarrow & \mathrm{O}_{3}(\mathrm{~b}) & (\text { at location } \mathrm{b}) \\ \mathrm{NO}(\mathrm{b})+\mathrm{O}_{3}(\mathrm{~b}) & \rightarrow & \mathrm{NO}_{2}(\mathrm{~b})+\mathrm{O}_{2} & \text { (at location } \mathrm{b})\end{array}$

\section{[Table 2]}

\subsection{Weekday and weekend effect}

The normalised values of surface $\mathrm{O}_{3}$ concentration based on the difference between the average concentration of daily $\mathrm{O}_{3}$ and weekly average during weekdays and weekends at all stations are shown in Figure 3. The results show that the concentration of surface $\mathrm{O}_{3}$ was recorded at higher concentrations during the weekend compared to weekdays. The results also show decreasing concentrations of $\mathrm{O}_{3}$ precursors $\left(\mathrm{NO}_{\mathrm{x}}\right.$ and $\mathrm{CO}$ ) from weekdays to weekends. The pattern of higher $\mathrm{O}_{3}$ at weekends compared to weekdays has been recorded in other studies in Malaysia such as Latif et al. (2014) and Banan et al 
(2013). This pattern is usually seen in the suburban and rural areas which have significantly different numbers of motor vehicles during weekdays compared to weekends.

\section{[Figure 3]}

During weekdays, the number of motor vehicles on the road will increase compared to weekends due to the movement of people going to work and children going to school. The low concentration of NO emitted by motor vehicles as well as industrial activities, especially in the middle of the day, during the weekend will reduce the capability of NO titrate $\mathrm{O}_{3}$ in ambient air (Alghamdi et al., 2014; An et al., 2015; Wang et al., 2014). The concentration of $\mathrm{O}_{3}$ therefore will be higher during the weekend compared to weekdays. Titration of $\mathrm{O}_{3}$ by NO that is emitted by anthropogenic sources contributes to the weekend effect. The weekend effect seen at the stations in this study indicate that the profile of these stations are closer to suburban than urban due to the difference in the concentrations of $\mathrm{O}_{3}$ and $\mathrm{O}_{3}$ precursors between weekdays and weekends. Although some of these stations are urban-industrial stations due to the activities carried out, the population density is less than highly-urbanised city centres.

\subsection{Monthly variation of $\mathrm{O}_{3}$ concentration}

The monthly average daily maximum concentrations of surface $\mathrm{O}_{3}$ at all monitoring stations, except for station S7, were highest in August (Figure 4). This month can be considered the dry month in the Southeast Asian maritime continental area compared to other months of the year. Haze episodes usually occur due to biomass burning, particularly from Kalimantan, Indonesia, and will add to the amount of $\mathrm{O}_{3}$ precursors at the monitoring 
stations along the west coast and north of Borneo due to the wind direction of the southwest monsoon.

\section{[Figure 4]}

Based on the clustered HYSPLIT model provided in Supplementary 2, wind movement during the southwest monsoon originates from the southern part of Borneo. This wind influences the pollutant concentrations, which are dominated by biomass burning as well as emissions from urban and industrial areas along the west coast of Borneo. This wind movement is expected to contribute high amounts of surface $\mathrm{O}_{3}$ compared to the northeast monsoon. It should be pointed out that the local scale wind system such as the land-sea breeze may also modulate the concentration of pollutant near the coastal regions. However, the HYSPLIT model was driven by the large scale meteorological field and hence does not account for such effect in the calculation of the trajectories. According to He et al. (2010) haze episodes can contribute to the amount of polar organic compounds such as phthalic acid and cis-pinonic acid. These two acids showed strong linear relationships with maximum daily $\mathrm{O}_{3}$ concentrations throughout the entire sampling period during haze episodes occurring in Singapore in 2013. The high intensity of UV radiation during the dry period when there is less cloud cover may also contribute to the formation of surface $\mathrm{O}_{3}$ (Awang et al., 2016a; Geng et al., 2008; Xie et al., 2016). The wet conditions at the turn of the year (November to January) usually reduce the amount of surface $\mathrm{O}_{3}$ precursors in these stations due to washout of pollutants and high cloud cover.

\section{[Supplementary 2]}


Conversely Tawau station (S7) recorded the highest $\mathrm{O}_{3}$ concentrations between November and February, which is during the northeast monsoon. A likely reason for the difference is the location of the station. Unlike S1 - S6, which are located on the west coast of Borneo, Tawau (S7) is located on the east coast which is influenced by different wind directions. The wind during the northeast monsoon (Supplementary 3) is arriving from the sea to most of the stations on the west coast of Borneo. The northeast monsoon is expected to bring more surface $\mathrm{O}_{3}$ precursors because the wind during the northeast monsoon moves towards Tawau via land compared to the southwest monsoon, which brings in air masses over the sea.

\section{[Supplementary 3]}

\subsection{Yearly pattern of $\mathrm{O}_{3}$ concentration}

The time series of the annual mean of maximum concentrations of surface $\mathrm{O}_{3}$ are shown in Figure 5. The detailed information on trends based on $\mathrm{O}_{3}$ yearly maximum concentrations and yearly average $\mathrm{O}_{3}$ concentration, as well as $\mathrm{O}_{3}$ precursor $\left(\mathrm{NO}, \mathrm{NO}_{2}, \mathrm{CO}\right)$ yearly average concentrations, are presented in Table 3. A majority of stations (except S1 and S6) have recorded increasing averaged maximum concentrations of surface $\mathrm{O}_{3}$ over the analysed years. In particular, $\mathrm{O}_{3}$ recorded at stations $\mathrm{S} 3$ and $\mathrm{S} 5$ have increased by 0.26 and $0.28 \mathrm{ppbv} / \mathrm{year}$, respectively, which are larger than their respectively natural variability. From these two stations, only S3 shows a significant increased trend $(p<0.05)$. Stations S1 and S6, which are located near to congested city centres (Kuching and Kota Kinabalu), showed a decreasing trend. Generally, the linear trends of the maximum $\mathrm{O}_{3}$ corresponds to the changes of the annual mean of the $\mathrm{O}_{3}$ concentration despite different increasing rates, 
except at $\mathrm{S} 1$, where the average $\mathrm{O}_{3}$ concentration increased slightly $(0.09$ ppbv/year) when the maximum $\mathrm{O}_{3}$ decreases $(-0.18$ ppbv/year). This suggests that different processes modulate the changes at different part of the $\mathrm{O}_{3}$ distribution in these stations for the timescale considered. In particular, the yearly maximum value is a representative of midday maximum $\mathrm{O}_{3}$ concentration, which can be modulated by regionally generated photochemical episodes and meteorological factors. The annual averaged, on the other hand is based on total 24-h averaged values and can be mostly influenced by the magnitude of local emission and processes.

\section{[Figure 5]}

Overall, yearly variations of surface $\mathrm{O}_{3}$ concentrations are expected to be influenced by local and transboundary $\mathrm{O}_{3}$ precursors as well as variations in meteorological factors. Increasing yearly trends of $\mathrm{NO}_{2}$ concentrations ( $\mathrm{S} 1, \mathrm{~S} 2, \mathrm{~S} 3$ and $\left.\mathrm{S} 6\right)$ potentially increase the concentration of $\mathrm{O}_{3}$ in the sampling locations. Nevertheless, increasing trends of $\mathrm{NO}$ such as at $\mathrm{S} 6(0.22 \mathrm{ppbv} / \mathrm{year})$ and $\mathrm{S} 1(0.08 \mathrm{ppbv} / \mathrm{year})$ may also reduce the $\mathrm{O}_{3}$ due to the titration process. The high increasing trends of $\mathrm{O}_{3}$ at $\mathrm{S} 3$ can be associated with increasing trends of $\mathrm{NO}_{2}$ and decreasing trends of NO. On the other hand, a high reduction of NO compared to $\mathrm{NO}_{2}$ may influence the increasing trend of $\mathrm{O}_{3}$ at $\mathrm{S} 5$.

There was no clear indication of the influence of yearly CO trends on the concentrations of yearly surface $\mathrm{O}_{3}$. Decreasing trends of $\mathrm{CO}$, especially at $\mathrm{S} 1$ (-30.37 ppbv/year), may suggest the reduction of incomplete combustion from vehicles and industrial processes. The reduction of $\mathrm{CO}$ has led to increasing trends of $\mathrm{NO}_{2}$, which is expected to come from 
complete combustion processes. Nevertheless, due to increasing trends of NO, the concentrations of $\mathrm{O}_{3}$ were not found to be influenced by high concentrations of $\mathrm{NO}_{2}$ at this station. The trend of $\mathrm{CO}$ from $\mathrm{S} 4$ to $\mathrm{S} 7$, which correspond to the fluctuation of NO, was expected to be influenced by motor vehicle emissions. S3 showed unique CO, NO and $\mathrm{NO}_{2}$ trends, where an increasing trend of $\mathrm{CO}$ was not followed by an increasing trend of NO. $\mathrm{CO}$ at this station may have the capacity to increase the concentration of $\mathrm{CO}$ in the surrounding areas.

\subsection{Bivariate polar plot}

Hourly $\mathrm{O}_{3}$ and $\mathrm{NO}_{2}$ measurements are shown on bivariate polar plots to illustrate how the pollutant variations are affected by wind speed and wind direction. Polar plots have been applied to discriminate source types, provide additional information on complex windpollutant interactions and vertical updrafts (Carslaw et al., 2006; Tomlin et al., 2009; Westmoreland et al., 2007). General features observed are that all the seven stations show evidence of increases in $\mathrm{O}_{3}$ concentration as the wind speed increases (Figure 6). The low concentration of $\mathrm{NO}_{2}$ at high wind speed is expected as $\mathrm{NO}_{2}$ is dispersed in the presence of high temperatures and sunlight, with $\mathrm{NO}_{2}$ releasing an $\mathrm{O}$ radical that contributes to the formation of surface $\mathrm{O}_{3}$. The higher concentrations of $\mathrm{NO}_{2}$ at low wind speeds are the result of more stable atmospheric conditions and reduced advection that exist under low wind speed conditions. Despite the influence of urbanisation and industrial emissions, the sea breeze appears to play an important role in the distribution of the precursors of $\mathrm{O}_{3}$ (Latif et al., 2012). As mentioned by Physick and Abbs (1992), pollutants can be transported many kilometres inland by the sea breeze circulation. 


\section{[Figure 6]}

$\mathrm{S} 3$, which has the highest hourly surface $\mathrm{O}_{3}$ concentrations, appears to show an obvious maximum concentration when the wind is from the north and northwest. S4 also showed high $\mathrm{O}_{3}$ concentrations when the wind originated from the northwest. These features are observed with wind speeds between $5 \mathrm{~m} / \mathrm{s}$ to more than $30 \mathrm{~m} / \mathrm{s}$ for both stations (Figure 6). Bintulu (S3) and Miri (S4) stations are located close to the large petrochemical and natural gas industries in the northwest. S5 is an island where the sea breeze blows from almost all directions especially from the northeast, northwest and southwest. S1 and S6 stations did not show a clear pattern of concentration with wind direction. The high $\mathrm{O}_{3}$ concentrations were more scattered which indicates that the pollutant sources were the surrounding industrial activities and also long-range transport of air pollutants. An increase in $\mathrm{O}_{3}$ in Sibu (S2) was observed when the wind originated from the southwest, and for Tawau (S7) the $\mathrm{O}_{3}$ concentrations were apparent when the wind was from the south and southeast. Concentrations of $\mathrm{O}_{3}$ at these two stations are expected to originate from $\mathrm{O}_{3}$ precursors that are at high levels due to urbanisation activities surrounding the sampling stations. Nevertheless, $\mathrm{O}_{3}$ and its precursors coming from transboundary emissions such as biomass burning from the south and southwest directions will be important.

\subsection{Relationship between $\mathrm{O}_{3}$ and its precursors and meteorological factors}

Density plots were drawn to determine the relative influence of precursor concentrations and meteorological factors on surface $\mathrm{O}_{3}$ concentrations recorded at all stations (Figure 7). The plot of $\mathrm{O}_{3}$ against $\mathrm{NO}$ shows that higher $\mathrm{O}_{3}$ concentrations are mostly observed at low 
NO concentrations $(<10 \mathrm{ppbv})$. At higher $\mathrm{NO}$ concentrations, titration of $\mathrm{O}_{3}$ is expected to dominate the interaction between $\mathrm{O}_{3}$ and NO. The density and concentration of $\mathrm{O}_{3}$ were higher for $\mathrm{NO}_{2}\left(10\right.$ - 20 ppbv) compared to $\mathrm{NO}$. However, when the $\mathrm{NO}_{2}$ concentration was $>40 \mathrm{ppbv}, \mathrm{O}_{3}$ concentrations were much lower than the maximum concentration observed at $<20$ ppbv $\mathrm{NO}_{2}$. The negative relationship between $\mathrm{O}_{3}$ and $\mathrm{NO}_{2}$ is expected as $\mathrm{NO}_{2}$ is a precursor to $\mathrm{O}_{3}$. The plot of $\mathrm{O}_{3}$ against $\mathrm{CO}$ shows a similar profile to $\mathrm{NO}_{2}$ with the exception of higher $\mathrm{O}_{3}$ concentrations at high $\mathrm{CO}$ concentrations (> $4000 \mathrm{ppbv}$ ). The highest $\mathrm{O}_{3}$ concentrations were recorded when the $\mathrm{CO}$ concentration was around 500 to 1500 ppbv. Temperature shows a positive relationship with $\mathrm{O}_{3}$ until about $35{ }^{\circ} \mathrm{C}$, after which $\mathrm{O}_{3}$ concentration does not show an apparent increase despite increasing temperatures. In the plot of $\mathrm{O}_{3}$ against wind speed, the highest density of $\mathrm{O}_{3}$ concentrations are observed at speeds of $<5 \mathrm{~m} / \mathrm{s} . \mathrm{O}_{3}$ concentrations were recorded at the highest values when the wind speed was between 5 to $15 \mathrm{~m} / \mathrm{s}$. Due to the high humidity in this region throughout the year, the highest density of $\mathrm{O}_{3}$ is observed around relative humidity of 90\%. However, $\mathrm{O}_{3}$ concentrations above $60 \mathrm{ppbv}$ are only observed when relative humidity is less than $80 \%$. A reduction in humidity is typically accompanied by higher temperatures and hence the increase in $\mathrm{O}_{3}$ in Malaysia (Latif et al., 2014; Latif et al., 2012). Also, water molecules can react with the photolysis product of $\mathrm{O}_{3}$ and form hydroxyl radicals which subsequently contribute to $\mathrm{O}_{3}$ formation in the presence of other precursors (Seinfield and Pandis, 2006).

[Figure 7]

\section{Conclusion}


The results of the study show that the concentration of surface $\mathrm{O}_{3}$ in the northern part of Borneo (Malaysian region) are still lower than the maximum permissible value of 100 ppbv suggested by the Malaysian Air Quality Standard for 2015 (Interim period - 1). The concentration of surface $\mathrm{O}_{3}$ is expected to be influenced by the amount of $\mathrm{NO}_{x}$, particularly from motor vehicles and the petrochemical industry. Stations located near to petrochemical sources such as Bintulu (S3) and Miri (S4) reported higher concentrations of $\mathrm{O}_{3}$ than other stations. Higher ratios of $\mathrm{NO}_{2} / \mathrm{NO}$ at these stations showed that $\mathrm{NO}_{2}$ is a potential major contributor to the amount of $\mathrm{O}_{3}$. Titration processes due to the concentration of NO from motor vehicles reduce the concentration of surface $\mathrm{O}_{3}$, especially at the stations near to the city centre such as Kuching (S1) and Kota Kinabalu (S6) and especially during weekdays. At the weekend higher concentrations of $\mathrm{O}_{3}$ are observed. Meteorological factors, especially temperature, UV radiation and wind speed, are found to influence the concentration of surface $\mathrm{O}_{3}$ in Borneo. Local and regional winds are also found to influence the concentration of surface $\mathrm{O}_{3}$ as shown at the Labuan station (local effect). High concentrations of $\mathrm{O}_{3}$ during the southwest monsoon may be due to biomass burning (transboundary effect) but this needs more detailed study and investigation. Majority of the stations (except S1 and S6) have recorded increasing averaged maximum concentrations of surface $\mathrm{O}_{3}$ over the analysed years. The increasing significant trends may due to the combination of increasing trends of $\mathrm{NO}_{2}$ and decreasing trends of NO. The density plots shows that the concentration of surface $\mathrm{O}_{3}$ was highest when the concentration of its precursors were at a certain range $\left(\mathrm{NO}<10 \mathrm{ppb} ; \mathrm{NO}_{2}\right.$ : 10 20 ppbv; and CO: 500 - 1500 ppbv). Particular range of wind speed (5 to $15 \mathrm{~m} / \mathrm{s}$ ), temperature $\left(<35^{\circ} \mathrm{C}\right)$ and humidity $(<80 \%)$ were also found to be conducive for 
increasing surface $\mathrm{O}_{3}$.

This study suggests that more detailed studies of surface $\mathrm{O}_{3}$ and its precursors in Borneo are required, especially the relation of surface $\mathrm{O}_{3}$ to other $\mathrm{O}_{3}$ precursors such as VOCs from various anthropogenic and natural sources. To maintain the concentration of $\mathrm{O}_{3}$ below the maximum value, especially in the middle of the day, the concentrations of $\mathrm{O}_{3}$ precursors need to be monitored and controlled. The emission of $\mathrm{NO}_{\mathrm{x}}$ with high concentrations of VOCs will increase the concentration of surface $\mathrm{O}_{3}$ in the study areas, especially in areas located close to petrochemical industries. There is also a need to study the effects of the long-range transport of surface $\mathrm{O}_{3}$ and its precursors, such as emission from biomass burning in other parts of Southeast Asia, especially Kalimantan. This study indicates that the biomass burning, which occurs from June to September every year, can contribute to the high concentration of surface $\mathrm{O}_{3}$ in Malaysian Borneo.

\section{ACKNOWLEDGEMENTS}

The authors would like to thank Universiti Kebangsaan Malaysia for the Research University Grants (DIP-2014-005 and AP-2015-010). Special thanks to Malaysian Department of Environment (DOE) for providing air quality and meteorological data for the process of conducting our research. We would also like to thank the United Kingdom Natural Environment Research Council for support through their International Opportunity Fund project (NE/J016012/1).We gratefully acknowledge the NOAA Air Resources Laboratory (ARL) for the provision of the HYSPLIT transport and dispersion model and READY website (http://www.arl.noaa.gov/ready.html). We gratefully thank Natural 
Environment Research Council (NERC) openair project (http://www.openair-project.org/). Special thanks to Dr Rose Norman for proofreading this manuscript.

\section{References}

Ahamad, F., Latif, M.T., Tang, R., Juneng, L., Dominick, D., Juahir, H., 2014. Variation of surface ozone exceedance around Klang Valley, Malaysia. Atmos Res 139, 116127.

Alghamdi, M.A., Khoder, M., Harrison, R.M., Hyvärinen, A.P., Hussein, T., Al-Jeelani, H., et al., 2014. Temporal variations of O3 and NOx in the urban background atmosphere of the coastal city Jeddah, Saudi Arabia. Atmos Environ 94, 205-214.

Amin, N., 2014. Effect of ozone on the relative yield of rice crop in japan evaluated based on monitored concentrations. Water Air Soil Pollut 225.

An, J., Zou, J., Wang, J., Lin, X., Zhu, B., 2015. Differences in ozone photochemical characteristics between the megacity Nanjing and its suburban surroundings, Yangtze River Delta, China. Environ Sci Pollut Res 22, 19607-19617.

Anenberg, S.C., West, J.J., Fiore, A.M., Jaffe, D.A., Prather, M.J., Bergmann, D., et al., 2009. Intercontinental impacts of ozone pollution on human mortality. Environ Sci Technol 43, 6482-6487.

Assareh, N., Prabamroong, T., Manomaiphiboon, K., Theramongkol, P., Leungsakul, S., Mitrjit, N., et al., 2016. Analysis of observed surface ozone in the dry season over Eastern Thailand during 1997-2012. Atmos Res 178-179, 17-30.

Awang, N.R., Elbayoumi, M., Ramli, N.A., Yahaya, A.S., 2016a. Diurnal variations of 
ground-level ozone in three port cities in Malaysia. Air Qual Atmos Health 9, 2539.

Awang, N.R., Elbayoumi, M., Ramli, N.A., Yahaya, A.S., 2016b. The influence of spatial variability of critical conversion point $(\mathrm{CCP})$ in production of ground level ozone in the context of tropical climate. Aerosol Air Qual Res 16, 153-165.

Awang, N.R., Ramli, N.A., Yahaya, A.S., Elbayoumi, M., 2015. Multivariate methods to predict ground level ozone during daytime, nighttime, and critical conversion time in urban areas. Atmos Pollut Res 6, 726-734.

Banan, N., Latif, M.T., Juneng, L., Ahamad, F., 2013. Characteristics of surface ozone concentrations at stations with different backgrounds in the Malaysian Peninsula. Aerosol Air Qual Res 13, 1090-1106.

Bell, M.L., Zanobetti, A., Dominici, F., 2014. Who is more affected by ozone pollution? A systematic review and meta-analysis. Am J Epidemiol 180, 15-28.

Carslaw, D.C., Beevers, S.D., Ropkins, K., Bell, M.C., 2006. Detecting and quantifying aircraft and other on-airport contributions to ambient nitrogen oxides in the vicinity of a large international airport. Atmos Environ 40, 5424-5434.

Chaudhary, N., Agrawal, S.B., 2015. The role of elevated ozone on growth, yield and seed quality amongst six cultivars of mung bean. Ecotoxicol Environ Safety 111, 286294.

Debaje, S.B., 2014. Estimated crop yield losses due to surface ozone exposure and economic damage in India. Environ Sci Pollut Res 21, 7329-7338.

Draxler, R., Stunder, B., Rolph, G., Stein, A., Taylor, A., 2013. HYSPLIT4 User's Guide, Version 4. Air Resources Laboratory, National Oceanic and Atmospheric 
Administration (NOAA), Silver Spring, Maryland.

Eva, H., Lambin, E.F., 1998. Remote Sensing of Biomass Burning in Tropical Regions: Sampling Issues and Multisensor Approach. Remote Sens Environ 64, 292-315.

Geng, F., Tie, X., Xu, J., Zhou, G., Peng, L., Gao, W., et al., 2008. Characterizations of ozone, NOx, and VOCs measured in Shanghai, China. Atmos Environ 42, 68736883.

Ghude, S.D., Jena, C., Chate, D.M., Beig, G., Pfister, G.G., Kumar, R., et al., 2014. Reductions in India's crop yield due to ozone. Geophys Res Lett 41, 5685-5691.

Guo, Y., Li, S., Tawatsupa, B., Punnasiri, K., Jaakkola, J.J.K., Williams, G., 2014. The association between air pollution and mortality in Thailand. Sci Rep 4.

He, J., Zielinska, B., Balasubramanian, R., 2010. Composition of semi-volatile organic compounds in the urban atmosphere of Singapore: Influence of biomass burning. Atmos Chem Phys 10, 11401-11413.

Ishii, S., Bell, J., Marshall, F., 2007. Phytotoxic risk assessment of ambient air pollution on agricultural crops in Selangor State, Malaysia. Environ Pollut 150, 267-279.

Ismail, M., Abdullah, S., Si Yuen, F., Ghazali, N.A., 2016. A ten-year investigation on ozone and it precursors at Kemaman, Terengganu, Malaysia. Environ Asia 9, 1-8.

Jerrett, M., Burnett, R.T., Arden Pope Iii, C., Ito, K., Thurston, G., Krewski, D., et al., 2009. Long-term ozone exposure and mortality. New Engl J Med 360, 1085-1095.

Kulkarni, P.S., Bortoli, D., Domingues, A., Silva, A.M., 2016. Surface ozone variability and trend over urban and suburban sites in Portugal. Aerosol Air Qual Res 16, 138152.

Latif, M.T., Dominick, D., Ahamad, F., Khan, M.F., Juneng, L., Hamzah, F.M., et al., 
2014. Long term assessment of air quality from a background station on the Malaysian Peninsula. Sci Total Environ 482-483, 336-348.

Latif, M.T., Huey, L.S., Juneng, L., 2012. Variations of surface ozone concentration across the Klang Valley, Malaysia. Atmos Environ 61, 434-445.

Lee, D.S., Holland, M.R., Falla, N., 1996. The potential impact of ozone on materials in the U.K. Atmos Environ 30, 1053-1065.

Levy, J.I., Chemerynski, S.M., Sarnat, J.A., 2005. Ozone exposure and mortality: An empiric bayes metaregression analysis. Epidemiololgy 16, 458-468.

Permadi, D.A., Kim Oanh, N.T., 2008. Episodic ozone air quality in Jakarta in relation to meteorological conditions. Atmos Environ 42, 6806-6815.

Physick, W.L., Abbs, D.J., 1992. Flow and plume dispersion in a coastal valley. J Appl Meteorol 31, 64-73.

Pochanart, P., Kreasuwun, J., Sukasem, P., Geeratithadaniyom, W., Tabucanon, M.S., Hirokawa, J., et al., 2001. Tropical tropospheric ozone observed in Thailand. Atmos Environ 35, 2657-2668.

Ren, C., Williams, G.M., Mengersen, K., Morawska, L., Tong, S., 2008. Does temperature modify short-term effects of ozone on total mortality in 60 large eastern US communities? - An assessment using the NMMAPS data. Environ Intern 34, 451458.

Seinfield, P., Pandis, S.N. Atmospheric Chemistry and Physics: From Air Pollution to Climate Change. New York: J. Wiley, 2006.

Shao, P., An, J., Xin, J., Wu, F., Wang, J., Ji, D., et al., 2016. Source apportionment of VOCs and the contribution to photochemical ozone formation during summer in 
the typical industrial area in the Yangtze River Delta, China. Atmos Res 176-177, 64-74.

Sicard, P., De Marco, A., Troussier, F., Renou, C., Vas, N., Paoletti, E., 2013. Decrease in surface ozone concentrations at Mediterranean remote sites and increase in the cities. Atmos Environ 79, 705-715.

Sicard, P., Serra, R., Rossello, P., 2016. Spatiotemporal trends in ground-level ozone concentrations and metrics in France over the time period 1999-2012. Environ Res $149,122-144$.

Stavrakou, T., Müller, J.F., Bauwens, M., De Smedt, I., Van Roozendael, M., Guenther, A., et al., 2014. Isoprene emissions over Asia 1979-2012: Impact of climate and land-use changes. Atmos Chem Phys 14, 4587-4605.

Taraborrelli, D., Lawrence, M.G., Crowley, J.N., Dillon, T.J., Gromov, S., Groß, C.B.M., et al., 2012. Hydroxyl radical buffered by isoprene oxidation over tropical forests. Nat Geosci 5, 190-193.

Tie, X., Li, G., Ying, Z., Guenther, A., Madronich, S., 2006. Biogenic emissions of isoprenoids and NO in China and comparison to anthropogenic emissions. Sci Total Environ 371, 238-251.

Tomlin, A., Smalley, R., Tate, J., Barlow, J., Belcher, S., Arnold, S., et al., 2009. A field study of factors influencing the concentrations of a traffic-related pollutant in the vicinity of a complex urban junction. Atmos Environ 43, 5027-5037.

Tu, J., Xia, Z.G., Wang, H., Li, W., 2007. Temporal variations in surface ozone and its precursors and meteorological effects at an urban site in China. Atmos Res 85, 310-337. 
Van Dingenen, R., Dentener, F.J., Raes, F., Krol, M.C., Emberson, L., Cofala, J., 2009. The global impact of ozone on agricultural crop yields under current and future air quality legislation. Atmos Environ 43, 604-618.

Vingarzan, R., 2004. A review of surface ozone background levels and trends. Atmos Environ 38, 3431-3442.

Wang, X., Mauzerall, D.L., 2004. Characterizing distributions of surface ozone and its impact on grain production in China, Japan and South Korea: 1990 and 2020. Atmos Environ 38, 4383-4402.

Wang, Y.H., Hu, B., Ji, D.S., Liu, Z.R., Tang, G.Q., Xin, J.Y., et al., 2014. Ozone weekend effects in the Beijing-Tianjin-Hebei metropolitan area, China. Atmos Chem Phys 14, 2419-2429.

West, J.J., Fiore, A.M., Horowitz, L.W., Mauzerall, D.L., 2006. Global health benefits of mitigating ozone pollution with methane emission controls. P Natl Acad Sci USA 103, 3988-3993.

Westmoreland, E.J., Carslaw, N., Carslaw, D.C., Gillah, A., Bates, E., 2007. Analysis of air quality within a street canyon using statistical and dispersion modelling techniques. Atmos Environ 41, 9195-9205.

Xie, M., Zhu, K., Wang, T., Chen, P., Han, Y., Li, S., et al., 2016. Temporal characterization and regional contribution to $\mathrm{O} 3$ and $\mathrm{NOx}$ at an urban and a suburban site in Nanjing, China. Sci Total Environ 551-552, 533-545.

Yang, W.S., Wang, X., Deng, Q., Fan, W.Y., Wang, W.Y., 2014. An evidence-based appraisal of global association between air pollution and risk of stroke. Int $\mathbf{J}$ Cardiol 175, 307-313. 
Zhang, Q., Yuan, B., Shao, M., Wang, X., Lu, S., Lu, K., et al., 2014. Variations of ground-level $\mathrm{O} 3$ and its precursors in Beijing in summertime between 2005 and 2011. Atmos Chem Phys 14, 6089-6101.

\section{Table's Caption}

Table 1: Locations of air quality station around the Borneo Island (Sabah and Sarawak, Malaysia) and descriptive data for hourly surface $\mathrm{O}_{3}$ hourly concentration from 2002 until 2013

Table 2: Ratio of $\mathrm{NO}_{2} / \mathrm{NO}$ concentrations between 12 pm and 4 pm $(2002-2013)$

Table 3: Yearly averaged $\mathrm{O}_{3}$ trend for hourly maximum $\mathrm{O}_{3}$, and yearly averaged $\mathrm{O}_{3}$ trend for hourly average $\mathrm{O}_{3}$ and its precursors $(2002-2013)$. Values in bold are significant at $p<0.05$.

\section{Figure's Caption}

Figure 1: Location of seven selected air quality monitoring stations

Figure 2: The diurnal pattern of surface $\mathrm{O}_{3}$ and its precursors at all monitoring stations. Only station $\mathrm{S} 1$ recorded concentration of $\mathrm{NMHC}$ and $\mathrm{UV}_{\mathrm{b}}$

Figure 3: Concentration of surface $\mathrm{O}_{3}$ and its precursors $\left(\mathrm{CO}\right.$ and $\left.\mathrm{NO}_{\mathrm{x}}\right)$ during week days and weekend

Figure 4: Monthly surface $\mathrm{O}_{3}$ daily maximum recorded at the monitoring stations

Figure 5: Yearly mean of daily maximum $\mathrm{O}_{3}$ concentration recorded at the monitoring stations

Figure 6: Bivariate plot of $\mathrm{O}_{3}$ (ppbv) at each station. The centre of each plot represents wind speed, starting from zero and increasing radially outward. The $\mathrm{O}_{3}$ concentration is coded using a colour scale. 
Figure 7: Scatter plot between $\mathrm{O}_{3}$ and its precursors $\left(\mathrm{CO}, \mathrm{NO}\right.$ and $\left.\mathrm{NO}_{2}\right)$; and between $\mathrm{O}_{3}$ and meteorological factors (Temperature, Humidity and Wind Speed). 


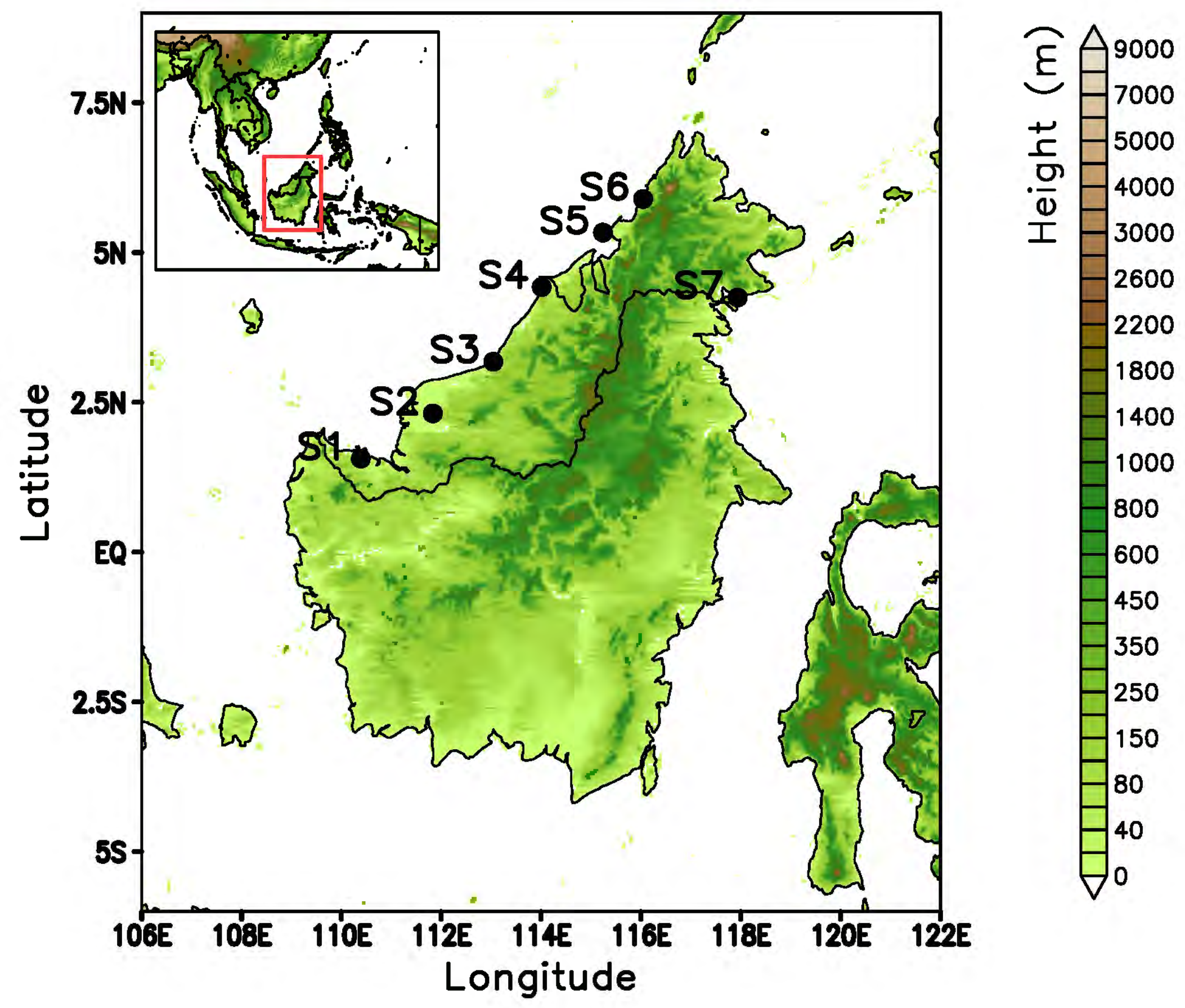




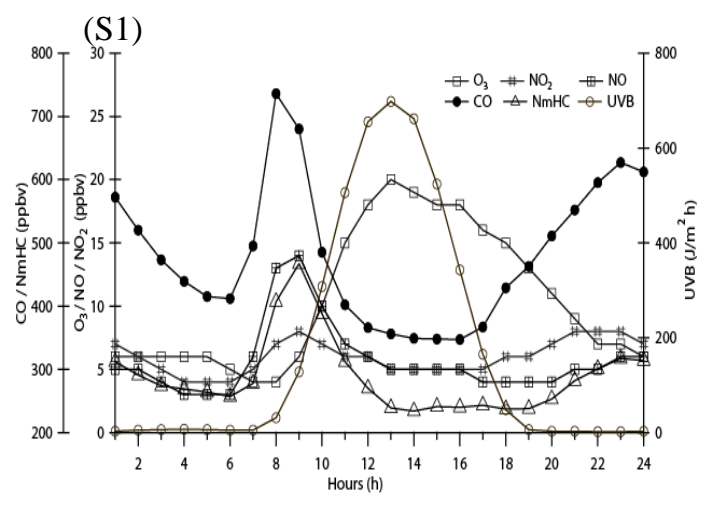

(S2)
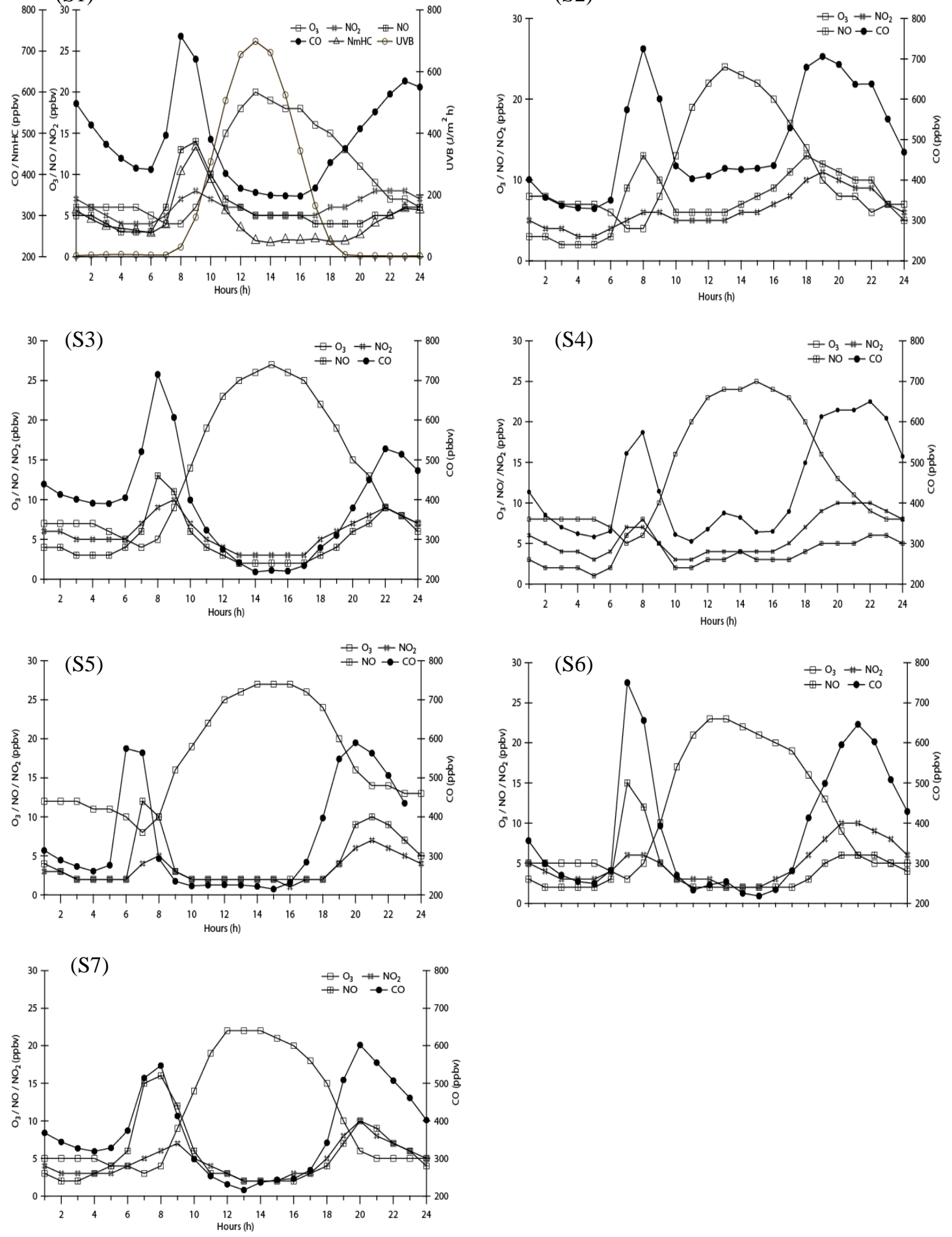
Figure 3
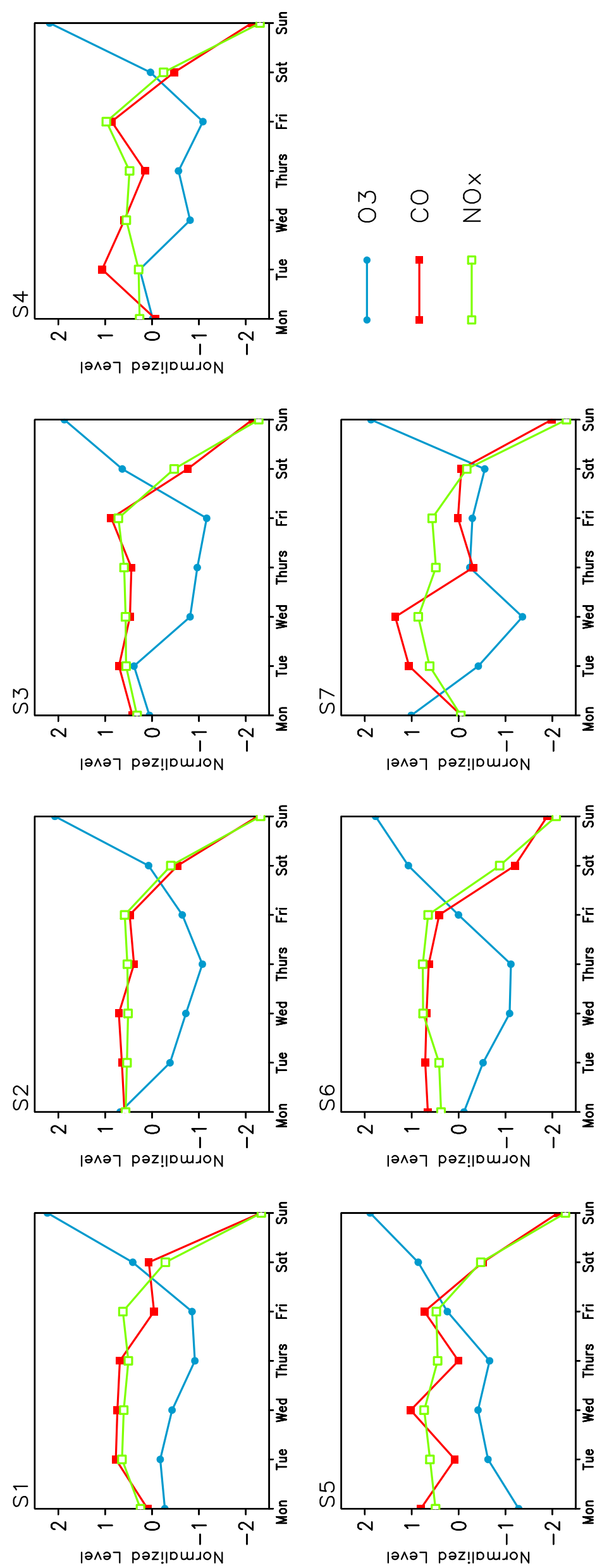

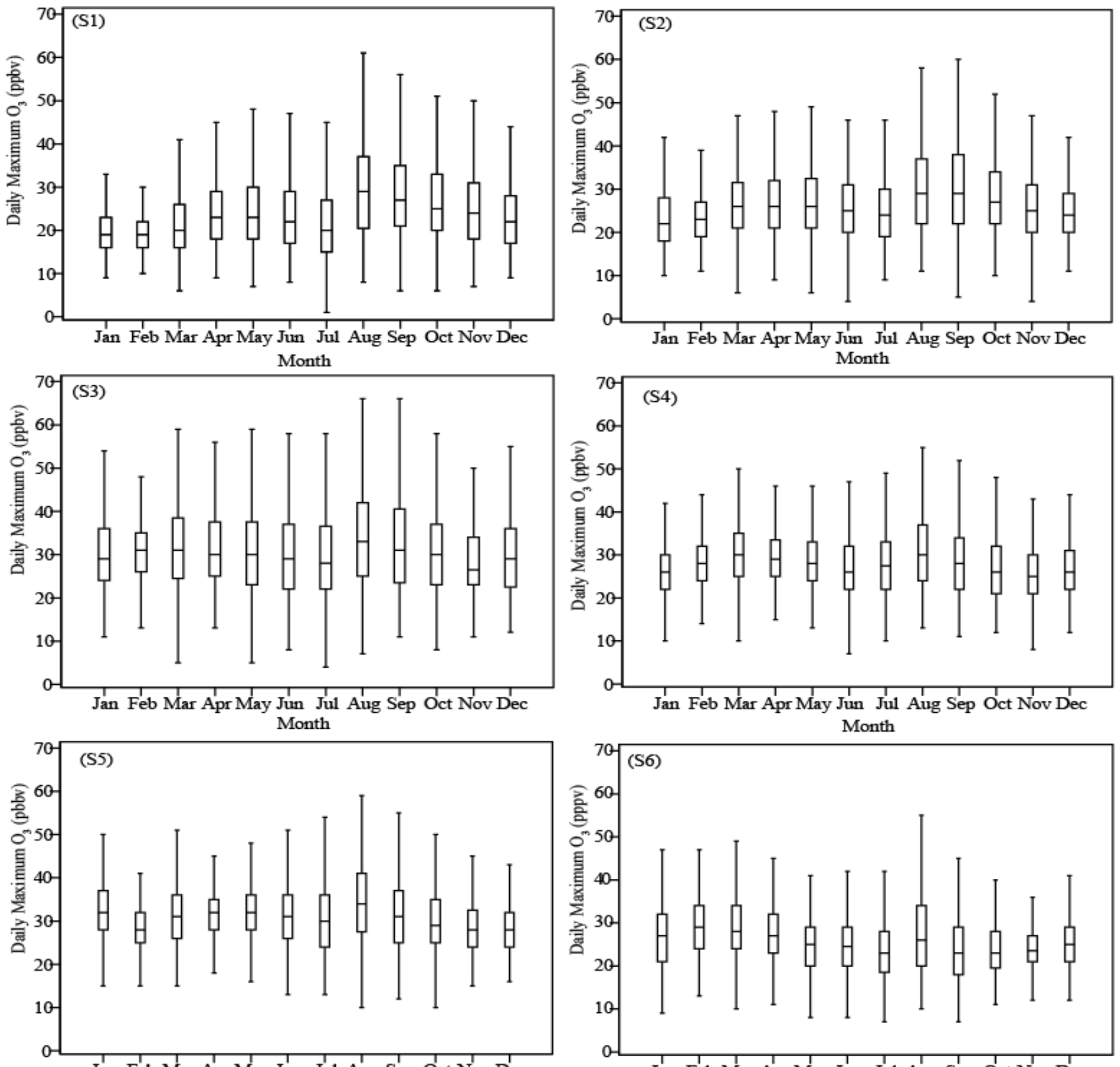

Jan Feb Mar Apr May Jun Jul Aug Sep Oct Nov Dec

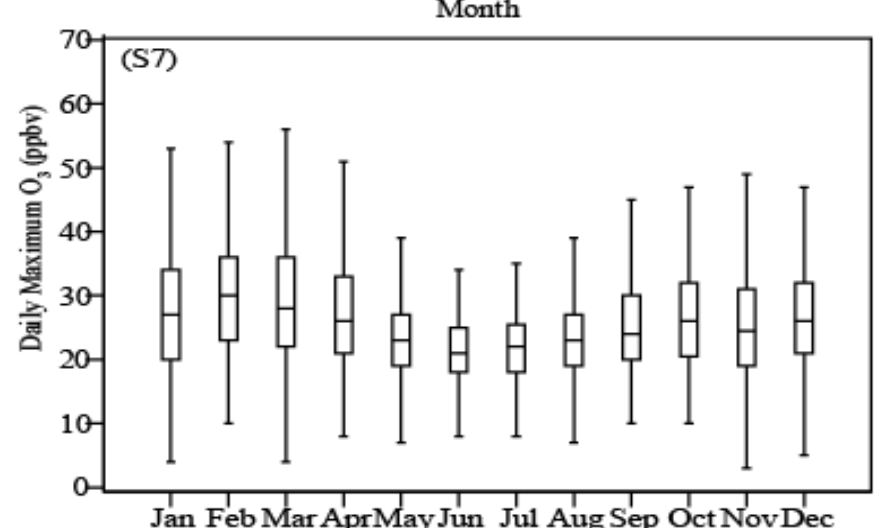

Jan Feb Mar Apr May Jun Jul Aug Sep Oct Nov Dec Month 
Figure 5
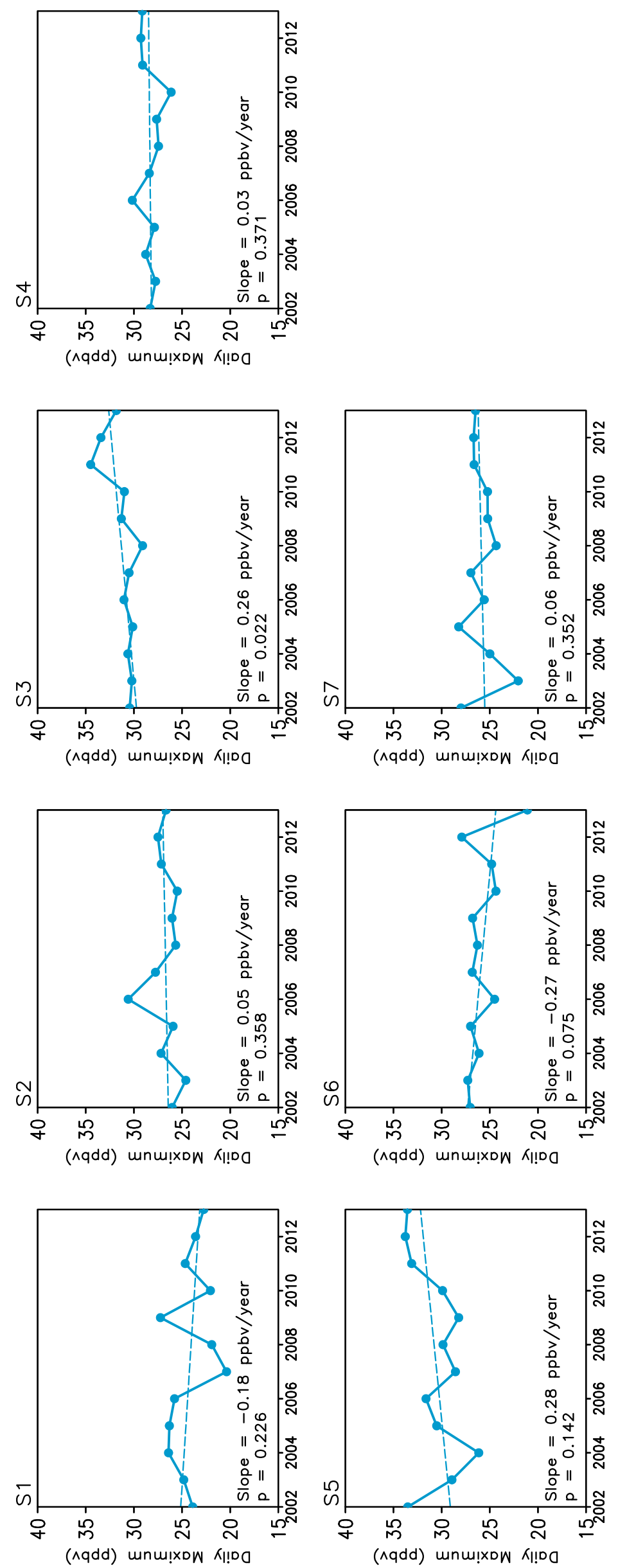

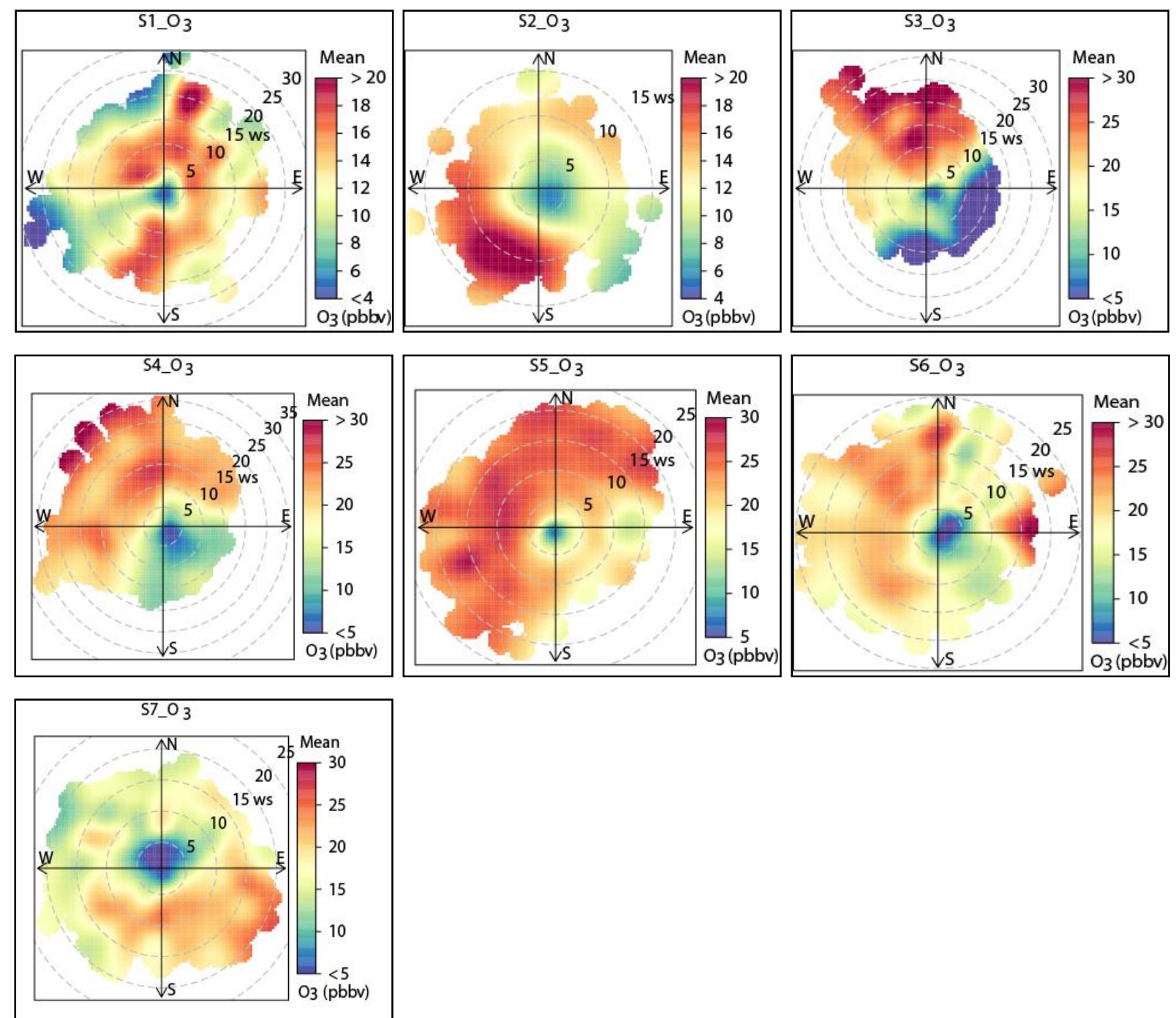

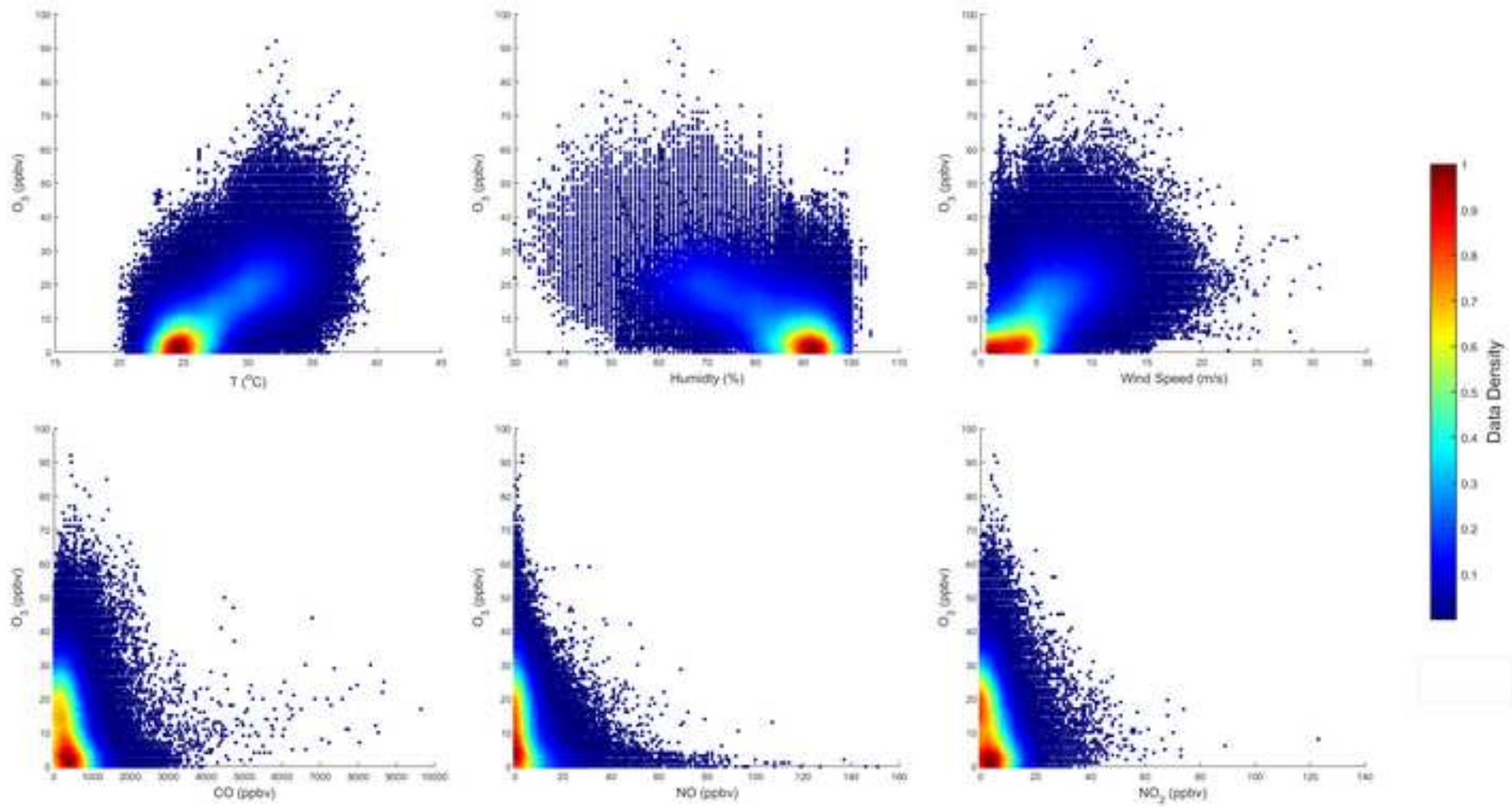
Table 1: Locations of air quality station around the Borneo Island (Sabah and Sarawak, Malaysia) and descriptive data for hourly surface $\mathrm{O}_{3}$ hourly concentration from 2002 until 2013

\begin{tabular}{|c|c|c|c|c|c|c|c|c|}
\hline \multirow{3}{*}{ Location } & \multicolumn{2}{|l|}{ Coordinate } & Altitude $^{a}$ & $\begin{array}{l}\text { Missing } \\
\text { value }^{b}\end{array}$ & & urly Ozone & Concentr: & ition \\
\hline & & & & & & Standard & & \\
\hline & Latitude & Longitude & $(\mathrm{m})$ & $(\%)$ & Average & Deviation & Median & Maximum \\
\hline Kuching (S1) & ${\mathrm{N} 01^{\circ} 33.734}^{\circ} 33$ & $\mathrm{E} 110^{\circ} 23.329$ & 7 & 12 & 24 & 10 & 22 & 82 \\
\hline Sibu (S2) & $\mathrm{N}^{\circ} 2^{\circ} 18.856$ & $\mathrm{E} 111^{\circ} 49.906$ & 9 & 9 & 27 & 9 & 25 & 67 \\
\hline Bintulu(S3) & $\mathrm{N}^{\circ} 3^{\circ} 10.587$ & $\mathrm{E} 113^{\circ} 02.433$ & 8 & 10 & 31 & 11 & 30 & 92 \\
\hline Miri (S4) & $\mathrm{N}^{\circ} 4^{\circ} 25.456$ & $\mathrm{E} 114^{\circ} 00.731$ & 6 & 8 & 28 & 8 & 28 & 80 \\
\hline Labuan (S5) & $\mathrm{N}^{\circ} 5^{\circ} 19.980$ & $\mathrm{E} 115^{\circ} 14.315$ & 15 & 10 & 31 & 8 & 30 & 77 \\
\hline Kota Kinabalu (S6) & $\mathrm{N}^{\circ} 5^{\circ} 53.623$ & $\mathrm{E} 116^{\circ} 02.596$ & 8 & 11 & 26 & 8 & 25 & 61 \\
\hline Tawau (S7) & N04 ${ }^{\circ} 15.016$ & $\mathrm{E} 117^{\circ} 56.166$ & 7 & 14 & 26 & 9 & 25 & 69 \\
\hline
\end{tabular}

Note: ${ }^{a}$ Altitude base on above sea level (ASL)

${ }^{b}$ Missing value based on data collection from starting date 
Table 2: Ratio of $\mathrm{NO}_{2} / \mathrm{NO}$ concentrations between $12 \mathrm{pm}$ and $4 \mathrm{pm}(2002-2013)$

\begin{tabular}{llllll}
\hline Station & $\mathbf{1 2} \mathbf{~ p m}$ & $\mathbf{1} \mathbf{~ p m}$ & $\mathbf{2} \mathbf{~ p m}$ & $\mathbf{3} \mathbf{~ p m}$ & $\mathbf{4} \mathbf{~ p m}$ \\
\hline S1 & 0.90 & 0.97 & 0.98 & 1.06 & 1.19 \\
S2 & 0.94 & 0.91 & 0.84 & 0.82 & 0.80 \\
S3 & 3.21 & 4.70 & 5.42 & 5.36 & 5.67 \\
S4 & 4.07 & 3.49 & 3.44 & 4.53 & 4.77 \\
S5 & 0.98 & 0.87 & 0.81 & 0.84 & 0.75 \\
S6 & 1.19 & 1.07 & 1.11 & 1.19 & 1.44 \\
S7 & 1.05 & 1.04 & 1.03 & 1.06 & 1.10 \\
\hline
\end{tabular}

Table 3: Yearly averaged $\mathrm{O}_{3}$ trend for hourly maximum $\mathrm{O}_{3}$, and yearly averaged $\mathrm{O}_{3}$ trend for hourly average $\mathrm{O}_{3}$ and its precursors $(2002-2013)$. Values in bold are significant at $p<0.05$.

\begin{tabular}{lc|cccc}
\hline Station & $\begin{array}{c}\text { Yearly Maximum trend } \\
\text { (ppbv/year) }\end{array}$ & \multicolumn{4}{c}{$\begin{array}{c}\text { Yearly } \\
\text { Average trend } \\
\text { (ppbv/year) }\end{array}$} \\
\cline { 2 - 6 } & $\mathrm{O}_{3}$ & $\mathrm{O}_{3}$ & $\mathrm{NO}$ & $\mathrm{NO}_{2}$ & $\mathrm{CO}$ \\
\hline S1 & -0.18 & 0.09 & 0.03 & $\mathbf{0 . 3 1}$ & $\mathbf{- 3 0 . 3 7}$ \\
S2 & 0.05 & 0.13 & $\mathbf{- 0 . 2 0}$ & $\mathbf{0 . 3 0}$ & $\mathbf{- 2 1 . 7 5}$ \\
S3 & $\mathbf{0 . 2 6}$ & $\mathbf{0 . 1 4}$ & -0.07 & $\mathbf{0 . 0 8}$ & 2.87 \\
S4 & 0.03 & $\mathbf{0 . 1 3}$ & $\mathbf{- 0 . 1 9}$ & -0.05 & $\mathbf{- 1 9 . 7 9}$ \\
S5 & 0.28 & 0.16 & $\mathbf{- 0 . 2 4}$ & -0.03 & $\mathbf{- 1 1 . 5 7}$ \\
S6 & -0.27 & -0.10 & $\mathbf{0 . 2 2}$ & $\mathbf{0 . 2 7}$ & 1.29 \\
S7 & 0.06 & 0.08 & $\mathbf{0 . 3 9}$ & $\mathbf{0 . 2 8}$ & 11.18 \\
\hline
\end{tabular}

